\title{
PENDIDIKAN BERBASIS ENTREPRENEUR DALAM LEMBAGA PENDIDIKAN SEBAGAI UPAYA UNTUK MENGURANGI KEMISKINAN
}

\author{
Tejo Nurseto \\ Universitas Negeri Yogyakarta \\ e-mail: tejonurseto@yahoo.co.id
}

\begin{abstract}
ABSTRAK
Poverty is a way of entry for the new century of colonialism. Future generations should be able to fight for this nation's wealth. The education of entrepreneurship is a way to reduce poverty; it is an education concept encouraging students to be creative and innovative in doing something. The pattern of such education requires learners to be productive. Entrepreneurship education is educational framework that directs learners to be quick in understanding and probing the economic and social needs of the surrounding community. Government should be willing to provide sufficient funds so that the process of entrepreneurship education can run smoothly.Even the community should be more active and intense in monitoring the development of entrepreneurial education if they want the progress of their nation, not only being a nation of coolie by sending migrant workers abroad, mostly of them are maid workers. This country is rich in natural resources, were it supported by resources having a high entrepreneurial spirit it would become a prosperous state so that by itself poverty would be far reduced. Poverty will evaporate into the history and transform to be memories that only can be remembered in museums.
\end{abstract}

Keywords: entrepreneurship, education of entrepreneurship, poverty.

\section{PENDAHULUAN}

Siapa hendak memungkiri Indonesia adalah negara kaya raya. Namun negara ini memiliki sekitar 40 juta rakyat miskin dan lebih dari 9 juta orang pengangguran. Seperti yang dikemukakan oleh Ciputra-seorang pengusaha sukses dan penggagas pendidikan entrepreneur, bahwa negara yang kaya sumber daya alam tidak serta merta dapat menjadi Negara yang sejahtera.

Mengapa? premis yang dikemukakan Ciputra sangat sederhana bahwa Negara kita yang kaya ini kekurangan entrepreneur. Beliau mengutip pendapat David Mc Celland seorang ilmuan social-pembangunan yang terkenal dengan konsep
Need for Achievement bahwa suatu Negara akan menjadi makmur apabila mempunyai entrepreneur paling sedikit $2 \%$ dari total jumlah penduduk negara tersebut. Ciputra mengutip dari data Global Entrepreneurship Monitor (GEM) dan menyajikan perbandingan antara Indonesia, Singapura dan As. Pada 2005, menurut GEM, singapura memiliki 7,2\% entrepreneur dari total penduduknya, padahal 2001 hanya 2,1\%. Lalu, di Amerika serikat pada tahun 1983 dengan jumlah penduduk 280 juta sudah ada 6 juta entrepreneur atau sudah sekitar 2,14\% dari seluruh penduduknya. Menurut data statistik Ciputra, Indonesia hanya memiliki 400.000 entrepreneur atau sekitar $0,18 \%$ dari total populasi. 
Jumlah penganggur terdidik di Indonesia setiap tahun terus bertambah, seiring dengan diwisudanya sarjana baru lulusan berbagai perguruan tinggi (PT). Para sarjana pengangguran itu tidak hanya lulusan terbaik PT swasta, tetapi juga PT negeri kenamaan.

Data Biro Pusat Statistik (BPS) menyebutkan jumlah sarjana (S-1) pada Februari 2007 sebanyak 409.900 orang. Setahun kemudian, tepatnya Februari 2008 jumlah pengangguran terdidik bertambah 216.300 orang atau sekitar 626.200 orang. Jika setiap tahun jumlah kenaikan rata-rata 216.300, pada Februari 2012 terdapat lebih dari 1 juta pengangguran terdidik. Belum ditambah pengangguran lulusan diploma (D-1, D-2, D-3) terus meningkat. Dalam rentang waktu 20072010 saja tercatat peningkatan sebanyak 519.900 orang atau naik sekitar $57 \%$.

Fakta dan angka tadi adalah sebuah denting kesadaran yang harus kita bangun bersama bahwa bangsa ini sudah terlena lebih 3,5 abad yang lalu, para penjajah telah mematikan semangat entrepreneur bangsa Indonesia. Belanda melaksanakan system tanam paksa dan mendidik manusia Indonesia untuk bangga menjadi pegawai pemerintah. Belanda bukan hanya menguras kekayaan alam negeri ini, melainkan juga mematikan ketrampilan soft skill maupun hard skill hingga kita tidak berdaya meskipun punya kekayaan berlimpah. Kini pemerintah dan segelintir orang Indonesia mulai sadar makna penting entrepreneurship, yaitu menumbuhkembangkan cikal bakal para entrepreneur. Negara ini sudah cukup dipenuhi olok-olok: bangsa"kuli" karena paling bayak mengirimkan tenaga kerja keluar negeri sebagai pembantu: bangsa 'terbelakang' dengan daya saing yang rendah: bangsa 'korup' dengan berbagai kasus korupsi antara birokrat dan pengusaha yang sudah akut serta berurat akar.
Ada tahapan dari usia sesorang untuk mulai membangun mimpi dan cita-cita lalu setahap demi setahap membangun kredibilitas dan kapabilitas sehingga dalam usia produktif ia mampu mengoptimalkan segenap potensinya sebagai manusia. Semua jelas memerlukan perencanaan dan entrepreneurship yang digadang-gadangkan semoga dapat masuk dalam manajemen anak, orang tua serta pendidik. Manajemen anak disini hanya sebuah istilah bagaimana sebuah keluarga merencanakan pengelolaan pendidikan dan masa depan anak-anaknya. Manajemen anak sama sekali tidak terkait dengan adanya fasilitas yang mendukung atau ujung-ujungnya duit. Pendidikan anak di masa ini membutuhkan biaya tinggi, bahkan diluar yang dapat kita pahami. Namun pendidikan berbiaya tinggi atau pendidikan elit tidaklah menjamin masa depan yang cemerlang bagi anak-anak. Kursus aneka macam juga tidak menjamin hal demikian akan membuat anak cerdas menghadapi hidup dimasa depannya kelak

\section{KESALAHPAHAMAN TENTANG ENTRE- PRENEUR}

Pendidikan entrepreneurship dapat dimaknai sebagai pendidikan calon pengusaha agar memiliki keberanian, kemandirian, serta ketrampilan sehingga meminimalkan kegagalan dalam usaha. Pendidikan entrepreneurship bukanlah pendidikan marketing atau penjualan yang mendidik seseorang untuk jadi pedagang. Akhirnya ada dua karakter seorang entrepreneur. Pertama entrepreneur sebagai creator yaitu menciptakan usaha atau bisnis yang benar-benar baru. Kedua, entrepreneur sebagai innovator, yaitu menggagas pembaruan baik dalam produksi, pemasaran, maupun pengelola dari usaha yang sudah ada sehingga menjadi lebih baik. Lalu kita sampai apakah sama antara entrepreneur dan pedagang?. Jawabnya tidak, seorang pedagang belum tentu seorang pengusaha jika ia tidak memiliki jiwa creator ataupun 
innovator dalam berdagang. Seorang pedagang bisa jadi hanya peniru, misalkan seseorang melihat orang lain yang berjiwa entrepreneur yang membuka usaha restoran jamur yang sama sekali belum ada. Calon pedagang tadi mencoba meniru usaha dengan membuka restoran jamur ditempat lain dengan cara menunggu dan meniru juga cara penjualan di restoran jamur pertama. Orang semacam ini hanya bisa disebut pedagang, bukan pengusaha atau entrepreneur.

Namun apabila seseorang terstimulus ide bisnisnya dari orang lain, kemudian menciptakan sebuah cara baru dalam produksi, pengemasan, dan penjualan, orang tersebut dapat disebut sebagai entrepreneur meskipun ia juga disebut seorang pedagang. Perbedaannya karena ada sesuatu yang baru diusahakan dengan membawa kemajuan signifikan terhadap usahanya, apakah itu perdagangan produk atau jasa.

Adakah anak-anak yang berbakat menjadi entrepreneur? Mungkin saja ada anak-anak yang memiliki gen entrepreneur karena orangtuanya pengusaha atau sebaliknya memiliki gen pengusaha, tetapi orang tuanya bukan pengusaha. Lalu dapat terjadi bahwa anak memang tidak memiliki gen atau bakat pengusaha. Lalu apakah mereka dapat menjadi pengusaha? Ciputra meyakini ada anak-anak yang secara alamiah memiliki bakat pengusaha. Namun jika bakat ini tidak diberi peluang untuk bertumbuh kembang akan mati terkubur, begitupun bakat entrepreneur inipun dapat dicangkokkan melalui pendidikan.

Memang kadang yang terjadi sungguh ektsrem bahwa entrepreneurship tidak berhubungan dengan tingkat pendidikan formal. Banyak kasus beberapa entrepreneur adalah mereka yang hanya lulusan SD dan SMP dan banyak juga yang dropout dari perguruan tinggi. Mereka disebut entrepreneurship karena mampu memanfaatkan peluang. Mereka telah terdidik secara langsung maupun tidak langsung sebagai entrepreneur.
Beberapa terlahir sebagai entrepreneur alamiah karena tekanan hidup dan keadaan yang memaksa.

Hal ini yang disoroti Ciputra bahwa anakanak berbakat akan sia-sia jika tidak distimulus dengan pendidikan entrepreneurship. Sebaliknya mereka yang tidak berbakatpun bisa dicangkokkan melalui pendidikan entrepreneurship dari usia dini hingga ke jenjang pendidikan tinggi.

Kadang-kadang dalam otak mahasiswa tersebut yang terpikir bagaimana supaya cepat lulus dan segera mendapatkan pekerjaan dari mengandalkan ijazah sarjananya, apakah itu menjadi karyawan swasta atau PNS. Lalu yang paling berbahaya lagi apabila diotak mereka mengharapkan kedudukan yang empuk diperusahaan dengan mengandalkan ijazah sarjananya, mental yang seperti ini yang berbahaya. Ijazah dan secarik kertas IPK, mereka anggap sebagai penguat daya saing dan daya tawar (bargaining position). Justru mereka lupa terhadap kekuatan diri sendiri sehingga ketika ditanya kelebihan yang ada pada dirinya, apa benefit yang dapat dia berikan untuk perusahaan,mereka pada umumnya gagap menjawab. Inilah pendidikan yang keliru dan entrepreneurhip masuk kategori sulit untuk diajarkan di kampus-kampus. Namun daripada tidak sama sekali ya harus tetap diajarkan. Hanya sebagai catatan yang mengajarkanpun harus para dosen yang berjiwa entrepreneur atau paling tidak juga berpengalaman sebagai pengusaha. Celaka sekali kalau yang mengajarkan juga tidak memahami entrepreneurship dan justru malah mengajarkan ilmu marketing

Ada 4 kategori entrepreneur yang dijelaskan Ciputra;

Pertama; dibagi menjadi 2, yaitu Owner Entrepreneur adalah pencipta dan pemilik bisnis, dan Professional Entrepreneur adalah orang-orang yang memiliki daya wirausaha, tetapi mempraktikkannya di perusahaan milik orang lain. 
Kedua; Government Entrepreneur, yaitu orang-orang yang duduk di pemerintahan dan memiliki jiwa serta ketrampilan wirausaha. Contoh konkret adalah mantan PM Singapura yang legendaries, Lee Kwan Yew yang mampu mengubah Singapura dari Negara yang miskin dan kumuh menjadi Negara kaya dan modern.

Ketiga; Social Entrepreneur, yaitu para pendiri organisasi-organisasi social kelas dunia yang menghimpun dana masyarakat untuk melaksanakan tugas-tugas social yang mereka yakini. Contoh konkret adalah Mohammad Yunus , peraih Nobel di bidang social yang mendirikan Grammeen Bank di Bangladesh.

Keempat; Academic Entrepreneur, yaitu para akademisi yang mengajar atau mengelola pendidikan dengan pola dan gaya entrepreneur sambil tetap menjaga tujuan mulia pendidikan.

\section{MENDIDIK ANAK JADI ENTREPRENEUR}

Zaman sudah berubah, kita tidak bisa lagi mendidik anak-anak kita dijaman sekarang dengan cara yang sama dengan orang tua kita dulu mendidik kita. Kita harus kreatif dan inovatif dalam mendidik anak dijaman sekarang. Anakanak harus di ajarkan spirit entrepreneur sejak dini. agar kelak generasi penerus kita tidak lagi menjadi bangsa kuli. Anak-anak dalam usia emas memiliki potensi luar biasa, terutama kerja otaknya. Stimulus orang tua sangat penting untuk membangkitkan potensi optimal anak-anak. Mungkin timbul keragu-raguan karena anda menginginkan anak anda menjadi dokter atau insinyur. Mari sama-sama kita ubah mindset, apapun cita-cita anak haruslah didukung, dan mereka tetap harus memiliki jiwa entrepreneur. Pikirkan kelak bagaimana mereka mengusahakan ilmunya, mengembangkan nya menemukan halhal baru (terobosan)dalam bidang yang mereka geluti. Sebagai contoh, seorang dokter yang memiliki rumah sakit untuk orang-orang yang tidak mampu dan mendapat predikat rumah sakit paling baik dan bersahabat. Contoh lain seorang dosen atau guru mempunyai lembaga pendidikan yang berkualitas tapi biaya pendidikannya tidak tinggi.

Tidak kalah penting adalah support dari orang tua si anak. Support orang tua kepada anaknya bisa berupa memberikan modal kepada si anak untuk menciptakan atau mengcreat benda sehingga bisa dijual. Selain modal support orang tua yang lain adalah dalam bentuk motivasi bahwa si anak. Bentuk motivasi itu antara lain bisa berwujud ucapan selamat ketika penjualan si anak mengalami keuntungan atau dorongan semangat untuk pantang menyerah atau membantu menganalisa kenapa rugi jika si anak mengalami kerugian. Support yang seperti ini sangat membantu bagi si anak karena dengan support anak akan semakin semangat manakala ia mendapatkan keuntungan dari usahanya tadi dan tidak patah semangat jika mengalami kerugian.

Disamping Orang tua, guru memegang peranan yang sangat penting dalam mendidik atau menanamkan kedalam mindset anak untuk menjadi seorang entrepreneur. Hal ini dikarenakan sebagian besar waktu anak dihabiskan disekolah dan kekuatan dari seorang guru. Guru hendaknya membina dan menumbuh kembangkan jiwa entrepreneurship ke anak, guru harus memberikan fasilitas dan kreatif dalam membina anak. Guru dalam mengajar harus bisa mengaitkan apa yang diajarkan dengan hal - hal yang berkaitan dengan entrepreneurship. Entrepreneurship sangat dibutuhkan oleh anak karena jika ini diberikan oleh guru secara kontinyu lambat laun akan tertanam di mindset anak tentang entrepreneurship. Kelak ketika dewasa nanti anak akan terbiasa dengan entrepreneurship dan yang terpenting lagi anak tidak akan takut dengan resiko akan rugi. 
Sekolah dan orang tua merupakan kunci sukses dari program entrepreneurshipsejak dini ini. Sekolah sebagai wadah bagi anak mendapatkan ilmu dan menerapkan ilmunya untuk melatih kembangkan jiwa entrepreneurshipnya, orangtua seba-gai motivator bagi si anak. Jika ini bisa diwujudkan pada semua atau sebagaian besar masyarakat dan sekolah - sekolah di Indonesia maka generasi entrepreneur yang kuat tidak akan kekurangan. Entrepreneur yang kuat dan dengan jumlah yang banyak membuat bangsa ini semakin kokoh dalam menjaga stabilitas ekonomi bangsa. Ekonomi yang stabil membuat bangsa ini kuat terhadap badai krisis keuangan ataupun krisis global yang terjadi saat ini. Di samping menjaga stabilitas ekonomi bangsa dengan banyaknya $E n$ trepreneur banyak memberikan lapangan pekerjaan bagi masyarakat luas.

\section{PENDIDIKAN BERBASIS ENTREPRENEUR}

Sekolah harus memberikan support para guru dalam mengkreasikan ide entrepreneurship kepada anak melalui berbagai program. Program-program tersebut bisa melalui kurikulum pendidikan atau kegiatan kesiswaan yang mengarah kepada kewirausahaan. Support sekolah ini kunci dari keberhasilan guru karena bagaimana mungkin guru menanamkan jiwa entrepreneurship kepada anak jika sekolah tempatnya mengajar tidak mempunyai kurikulum ataupun kegiatan kesiswaan yang berkaitan dengan entrepreneurship .

Masuknya nilai-nilai entrepreneurship pada kurikulum sekolah mewajibkan guru untuk selalu mengaitkan pelajaran yang diajarkan terlepas bidang studi apapun yang diajarkan untuk selalu dikaitkan dengan entrepreneurship. Hal ini yang akan membuat anak mempunyai banyak pengetahuan entrepreneurship. Kegiatan sekolah yang berkaitan dengan entrepreneurship merupakan penyeimbang bagi anak untuk menerapkan apa yang ia peroleh dari pelajaran yang diajarkan oleh guru tersebut. Misal saat pelajaran matematika guru bisa me-ngajarkan pelajaran uang sehingga anak mengetahui tentang nilai uang serta contoh-contoh penggunaannya. Dari pelajaran tadi sekolah membuat kegiatan yang membuat anakanak kreatif dalam menerapkan ide-ide polosnya. Misalnya anak diminta untuk membuat sesuatu kemudian diminta untuk menghitung berapa modal yang dibutuhkan kemudian jika sudah jadi anak diminta untuk menjual hasil karyanya tersebut. Penjualan bisa dilakukan kepada siapa saja, bisa kepada teman - temannya, gurunya, wali murid, ataupun masyarakat umum. Dari contoh tadi disamping anak secara tidak sadar telah belajar menjadi seorang entrepreneur. Dalam proses pembuatan pembuatan sampai penjualan tadi anak pasti mengalami banyak hal. Ini yang menjadikan pengalaman dari anak tersebut. Mulai dari bagaimana ia mencari ide, menuangkannya menjadi nyata kemudian bagaimana ia menjualnya. Bukan tidak mungkin hasil akhirnya anak tidak selalu untung atau me-ngalami kerugian dari apa yang telah ia lakukan tadi. Tapi jika hal ini guru dan sekoalh bisa secara kontinyu mensupport kegiatan - kegiatan atau pola pembelajaran yang seperti ini maka sepuluh atau dua puluh tahun yang akan anak - anak tadi akan menjadi entrepreneur - entrepreneur yang sukses. Kegiatan seperti ini ibarat pepatah"seta;li tiga uang", selain anak belajar menjadi entrepreneur anak juga tetap belajar pelajaran yang telah diberikan oleh gurunya disekolah. Misalnya ia telah menggunakan pengetahuannya tentang nilai uang untuk pelajaran matematika, berani berbicara pada saat menjualkan barangnya untuk pelajaran bahasa Indonesia dan lain sebagainya.Memang harus ada kemauan,sekaligus konsep untuk merancang kurikulum entrepreneurship masuk ke level TK, bahkan mungkin Pendidikan Anak Usia Dini (PAUD) atau lebih popular disebut playgroup. 
Entrepreneurship tidak dapat diajarkan dengan pemaksaan atau proses pengarbitan meskipun sebagian besar entrepreneurship memang lahir dari keterpaksaan hidup atau kesulitan hidup yang memaksanya sejak kecil harus berusaha. Entrepreneurship adalah sebuah semangat perjuangan ,mempertahankan hidup,mengembangkan kreasi dan daya inovasi, serta berorientasi sekali lagi kepada keslamatan umat manusia serta makhluk di bumi ini.

Apabila selama ini perguruan tinggi tidak mampu melahirkan tenaga-tenaga terampil yang dibutuhkan dunia lapangan kerja, ini disebut kegagalan pendidikan tinggi. Perguruan tinggi tidak bisa memberikan yang terbaik bagi nasib dan masa depan bangsa ke depan. Perguruan tinggi tidak sepenuhnya berdedikasi tinggi bagi pengentasan pengangguran yang membanjiri negeri ini dan justru ikut menyumbangkan persoalan di tengah sosial dengan segala konsekuensi buruknya. Bila ada adigium bahwa perguruan tinggi menjadi tulang punggung utama guna memperbaiki kehidupan bangsa, itu pun masih perlu dibahas kembali dan dicarikan kebenarannya dalam konteks apakah itu. Jelas, ada yang salah dalam pengelolaan pendidikan tinggi di perguruan tinggi saat ini.

Ada yang tidak dan belum beres dalam mengelola pendidikan tinggi di perguruan tinggi. Ada konsep pemikiran yang tidak bersambungan antara harapan orang tua peserta didik untuk memasukkan dan menyekolahkan anak-anaknya di perguruan tinggi dengan para pemegang pendidikan tinggi tersebut. Apabila para orang tua peserta didik mengharapkan anak-anaknya mendapatkan ilmu pengetahuan yang bermanfaat dan selanjutnya bisa diaplikasikan dalam dunia kerja, ternyata harapan ideal para orang tua tersebut belum dan tidak didengar para pemegang pendidikan tinggi. Para pemegang pendidikan tinggi tidak mengetahui pesan nurani para orang tua tersebut sesungguhnya. Ada salah komunikasi lintas sektoral di antara dua kelompok tersebut. Ironisnya, selama pendidikan tingginya sesuai dengan misi dan visi perguruan tinggi akan tetapi tidak mencakup muatan pesan nurani para orang tua, perguruan tinggi tetap menjalankan pendidikan tingginya itu. Sangat jelas, antara keinginan para orang tua dan perguruan tinggi tidak bersatu dan dicobasatu-padukan. Sejatinya dan secara ideal, perguruan tinggi itu harus mengerti dan memahami kebutuhan para konsumen pendidikan, namun hal tersebut dibiarkan begitu saja dan tidak mendapat ruang kepedulian yang tinggi. Ini sungguh memilukan. Perguruan tinggi mementingkan kepentingan dirinya sendiri sementara kepentingan para orang tua dan peserta didik sebagai konsumen ditelantarkan dengan begitu saja. Sejumlah bukti perguruan tinggi tidak sepenuhnya berpihak pada kepentingan dan kebutuhan konsumen pendidikan, itu bisa dibaca dan diketahui di beberapa perguruan tinggi dengan program studi yang tidak dan kurang aplikatif.

Ada beberapa program studi yang tidak layak dipertahankan, itu pun masih dipertahankan keberadaannya. Seolah bertujuan untuk melengkapi program studi lainnya supaya kelihatan banyak program studi yang diberlangsungkan dalam perguruan tinggi tersebut. Sementara ada beberapa program studi yang sangat diminati konsumen pendidikan, program studi tersebut tidak digarap secara serius, sebut saja perlengkapan infrastruktur dan suprakstrukturnya. Ini sangat menunjukkan bahwa pengelolaan pendidikan tinggi selama ini tidak dikerjakan secara profesional.

Oleh karenanya, ketidakmampuan perguruan tinggi membaca kebutuhan lapangan dan kongkrit pun menjadi sebuah persoalan baru yang cukup merumitkan keadaan. Ini sesungguhnya yang justru akan menambah ketidakjelasan arah pendidikan tinggi di perguruan tinggi. Sangat jelas, hal sedemikian memberikan satu stigma buruk terhadap pendidikan tinggi yang selama ini diberlangsungkan. Pendidikan tinggi hanya dikerjakan apa 
adanya, tanpa dikonsep secara jelas dan matang. Pendidikan tinggi adalah sebuah proses penyelenggaraan pendidikan yang tidak memiliki dasar pemikiran sangat matang dan aplikatif, akan dibawa kemana arah pendidikannya. Hal sedemikian sungguh sebuah potret pendidikan tinggi yang muram dan sudah kehilangan identitas dirinya sebagai pendidikan yang siap mencetak generasi bangsa, yang dipersiapkan untuk mengisi seluruh lini kehidupan bangsa guna menggapai bangsa besar, maju dan makmur.

Pendidikan mempunyai peran penting untuk menciptakan kemajuan masyarakat. Dalam parkatiknya pendidikan harus mampu melahirkan generasi unggul, berprestasi dan berakhlak mulia. Namun, bila yang terjadi demikian, menandaskan adanya permasalahan mendasar dalam dunia pendidikan yang sebetulnya merupakan akar masalah pendidikan kita. Pendidikan yang hanya menhasilkan pengangguran akan menambah beban bangsa yang makin terpuruk. Pengangguran intelektual merupakan penyakit sosial yang menimbulkan keresahan-keresahan pada masyarakat oleh karena itu, bila kita memahami bahwa pendidikan merupakan sarana paling penting untuk menuai kesuksesan di masa depan.

Kita mestinya melihat pendidikan sebagai wahana jalan pintas bagi masa depan yang gilang gemilang. Sehingga, bekal pendidikan yang tinggi akan memberikan kompetensi, keunggulan dan keniscayaan bagi siapapun untuk masuk dalam ruang masa depan yang cerah merona. Maka, pendidikan harus ditempatkan menjadi ujung tombak bagi kemajuan bangsa. sebab, dengan banyaknya orang yang mengenyam pendidikan, tentunya kualitas suatu bangsa mempunyai nilai tawar yang tinggi pula.

\section{Program Studi yang Kongkrit}

Sejumlah perguruan tinggi selama ini belum mampu memberikan program studi yang kongkrit, yang dibutuhkan di lapangan dan justru semakin melangit. Sangat niscaya, perguruan tinggi tersebut akan dilibas oleh zaman dari tahun ke tahun. Apabila saat ini masih bisa bertahan, itu pun hanya menunggu waktu yang tepat untuk mau kolaps. Departemen Pendidikan Nasional mencatat jumlah program studi baru tersebut mencapai 761 program studi di 167 perguruan tinggi. Jauh lebih tinggi dari jumlah program studi yang ditutup pada tahun yang sama, yakni 113 program studi di 64 perguruan tinggi. Alasan utama karena ditutup adalah sangat sedikitnya peserta didik yang berminat masuk program tersebut dengan alasan utama pula sebab setelah lulus tidak bisa berbuat apa-apa..

Pendidikan tinggi masih ibarat menara gading yang bertengger di atas langit namun tidak melihat ke bawah, berupaya terjun ke lapangan, apa sesungguhnya yang terjadi di sana. Ini sama sekali kurang begitu dilakukan dengan sedemikian baik, optimal dan maksimal. Ada kesan bahwa perguruan tinggi sangat eksklusif terhadap realitas dan masyarakat sebagai konsumen pendidikan. Ada disparitas sosial sangat lebar di antara dua kelompok tersebut. Selama ini yang terjadi, perguruan tinggi menawarkan sekian program studi melangit dengan segala tawaran manis dan menggiurkan, akan segera bekerja setelah lulus. Iklan-iklan kebohongan publik disesumbarkan dengan sedemikian lancar, ibarat seseorang yang berjualan jamu atau obat di pasar. Padahal itu tong kosong nyaring bunyinya. Masyarakat sebagai konsumen pendidikan dicekoki dengan sekian janji sangat berbunga-bunga.

Oleh karenanya, guna memberi sebuah ketegasan dan keseriusan pendidikan tinggi terhadap kebutuhan konsumen pendidikan, pendidikan tinggi harus bisa memahami sesuatu yang 
diinginkan konsumen pendidikan. Pendidikan tinggi jangan memaksakan kehendaknya untuk diikuti konsumen pendidikan. Sebaliknya harus menyediakan program studi yang kongkrit yang sangat dibutuhkan konsumen pendidikan. Program studi kongkrit adalah ketika program studi tersebut bisa memberikan arah yang jelas, kemanakah para peserta didiknya akan mendapatkan pekerjaan setelah selesai di bangku pendidikan tinggi. Yang jelas, program pendidikan yang menitikberatkan pada jiwa entrepreneur (kewirausahaan) adalah sebuah keniscayaan yang perlu digarap secara serius oleh perguruan-perguruan tinggi di negeri ini. Ini sebagai tanggung jawab pendidikan tinggi dan tanggung jawab sosial bersama guna sesegera mungkin menuntaskan persoalan pengangguran.

Pendidikan entrepreneur adalah satu konsep pendidikan yang memberikan semangat pada peserta didik untuk kreatif dalam mengerjakan sesuatu hal. Pola pendidikan sedemikian ini menuntut peserta didik untuk bisa produktif. Pendidikan entrepreneur adalah kerangka pendidikan yang mengarahkan peserta didik untuk bisa cepat dalam memahami dan menelisik kebutuhan sosial sekitar. Peserta didik diharapkan dapat menggali potensi dirinya dengan sedemikian mendalam dan serius. Sebab setiap peserta didik itu memiliki potensi beragam yang tidak bisa disamakan setiap individunya. Sebab mereka beragam dalam segala hal.

Pendidikan entrepreneur diadakan dalam rangka memberikan motivasi dan pembinaan usaha. Hal sedemikian akan bisa berjalan secara baik bila ada perangkat-perangkat lain yang mendukung. Pendidikan tinggi dalam konteks sedemikian diharapkan mengadakan jaringanjaringan kerja sama dengan Usaha Mikro, Kecil dan Menengah (UMKM) yang banyak mengetahui tentang kewirasausahaan.

\section{Pendidikan Tinggi; Pendidikan Entrepreneur}

Menjawab tantangan sosial yang semakin mendesak, pengangguran kian waktu menjubel, maka pendidikan tinggi perlu diarahkan pada pendidikan entrepreneur namun tetap tidak menghilangan identitas lainnya sebagai lembaga pendidikan tinggi berorientasi pada research dan discovery. Pendidikan tinggi dituntut untuk menyemarakkan program pendidikannya yang berjiwa entrepreneur. Ada beberapa hal yang memberikan ciri dasar pendidikan entrepreneur. Pertama, pendidikan tersebut lebih menitikberatkan pada penggalian potensi diri setiap peserta didik. Sebut saja, apabila seorang peserta didik memiliki minat dan potensi kemampuan untuk berdagang, maka hal demikian perlu dikembangkan dengan sedemikian tajam. Ketika potensi demikian diketahui dan sudah bisa ditumbuhkan, ini kemudian mengarahkan peserta didik untuk dipompa semangat, upaya dan kejiwaan untuk menekuni itu. Ini bisa dikembangkan dan ditumbuhkan dengan sedemikian pesat ketika proses pembelajaran yang dikembangkan di pendidikan tinggi tersebut secara langsung berkenaan dengan minat dan potensi kemampuan yang dipunyai peserta didik tersebut. Memberikan beberapa contoh mengenai beberapa profil seseorang yang sudah sukses dalam bidang-bidang tertentu adalah satu penggerak utama dan maha utama supaya peserta didik semakin semangat dengan dunia yang ingin digelutinya itu.

Kedua, menyediakan para pengajar yang berlatar kewirausahaan adalah satu kemutlakan yang perlu dipenuhi. Ini berbicara konsep pendidikan entrepreneur yang jelas. Sebab dalam pendidikan entrepreneur, pengajar yang berlatar kewirausahaan memiliki cara dan model pengajaran yang berbeda dengan pengajar yang hanya memiliki pengetahuan teoritik namun tidak berpengalaman dalam dunia kewirausahaan. Seorang pengajar 
dengan nir-pengalaman kewirausahaan akan terkesan berdasarkan teks, namun tidak sesuai dengan kebutuhan dan pengalaman di lapangan. Sehingga proses pembelajarannya pun mengalami kekeringan nilai-nilai entrepreneur yang sesungguhnya perlu diwujudkan dalam proses pembelajaran sedemikian itu. Pendidikan entrepreneur berbicara hal-hal kongkrit yang perlu dipraktikkan, bukan hanya diteorikan.

Sangat jelas, ada perbedaan mendasar antara seorang pengajar yang berpengalaman sebagai seseorang yang bergerak dalam kewirausahaan dan bukan. Proses penyampaian materinya pun juga berbeda ketika memberikan semangat, minat dan suasana dalam pembelajaran. Ini sesungguhnya sangat penting diperhatikan sebab hal mendasar menjadi kunci utama ketika pendidikan entrepreneur digelar. Sehingga peserta didik pun akan berbeda menanggapi penyampaian seorang pengajar yang berlatar entrepreneur dan bukan. Seorang pengajar sangat menentukan apakah proses pembelajarannya berhasil atau tidak dicerna dan dipahami oleh peserta didik. Seorang pengajar adalah orang yang akan berperan penting untuk bisa memberikan pemahaman sangat mendalam apa itu entrepreneur sesungguhnya dan secara ideal. Sehingga seorang pengajar pun dituntut untuk memiliki kemampuan yang sesuai dengan bidangnya. Oleh karenanya, peran seorang pengajar pun sangat signifikan bagi keberlangsungan pembelajaran tersebut.

Ketiga, kehendak politik stakeholder perguruan tinggi sangat dibutuhkan dalam konteks ini. Sebab tanpa adanya kehendak politik yang baik dari perguruan tinggi terkait, ini sangat muskil akan melahirkan sebuah pendidikan tinggi yang baik pula. Oleh karenanya, para stakeholder perguruan tinggi diminta secara serius untuk melakukan satu orientasi pendidikan tinggi yang dibutuhkan lapangan dan pasar. Pendidikan tinggi yang berarah pada entrepreneur adalah sebuah keniscayaan. Sehingga melakukan format kurikulum pendidikan yang berjiwa entrepreneur pun disegerakan untuk digarap secara kongkrit dan praksis.

Kurikulum pendidikan tinggi yang berjiwa entrepreneur adalah dengan mendefinisikan ulang apa itu pendidikan yang dihubungkan dengan entrepreneur sebagai bagian komponen lain untuk menambah wawasan serta pengetahuan peserta didik saat terjun ke lapangan, ketika mereka selesai di bangku pendidikan tingginya. Mempersiapkan perangkat lunak (suprastruktur) yang terkait dengan kurukulum pendidikan entrepreneur adalah hal penting untuk bisa diberesi. Sebab ini adalah modal paling pokok ketimbang lainnya. Selanjutnya adalah mempersiapkan perangkatperangkat keras atau perangkat pendukung yang bisa mempercepat bagi tercapainya pelaksanaan pendidikan yang berjiwa entrepreneur di perguruan tinggi. Perguruan tinggi harus memenuhi itu semua.

\section{Sekolah Kejuruan}

Diakui maupun tidak, ada sebagian besar anak negeri ini yang tidak mampu melanjutkan pendidikannya ke perguruan tinggi dengan alasan mendasar; tingkat ekonomi orang tua yang tidak mampu secara finansial. Sehingga mereka hanya bisa menuntaskan pendidikan di tingkat Sekolah Menengah Atas atau sederajat. Kondisi anak-anak sedemikian itu tetap perlu mendapat perhatian besar dari sekolah-sekolah yang memiliki beberapa program untuk membina anak-anak terampil, kreatif dan mampu menciptakan lapangan pekerjaan sendiri. Yang jelas, basis utama sekolah yang bisa menampung anak-anak kurang mampu secara ekonomi adalah sekolah kejuruan. Sebab sekolah kejuruan lebih menitikberatkan pada pembentukan skill dan karakter anak didik. 
Mereka dilatih untuk membangun motivasi, semangat dan spirit hidup. Pola pendidikan di sekolah kejuruan adalah bersifat praktik dari pada teori. Persentase praktik lebih banyak ketimbang teori. Sehingga ini memungkinkan anak didik memiliki sebuah pengalaman pendidikan tertentu yang diupayakan nantinya dapat dimanfaatkan demi kepentingan dirinya di hari kemudian. Ambil contoh, sekolah kejuruan yang memberikan pendidikan entrepreneur, seperti usaha simpan pinjam (perkreditan) dapat menjadikan anak didik untuk tekun dalam bidang tersebut. Hal tersebut dapat diperkuat tingkat proses pelaksanaan pendidikan simpan pinjamnya ketika anak-anak didik dilatih dan dipekerja-bantukan dalam sebuah kantor simpan pinjam.

Dalam kerja kantor tersebut, mereka kemudian juga diperkenalkan dengan beberapa cara teknis bagaimana mengembangkan usaha simpan pinjam supaya uang di kantor tersebut dapat dikelola dengan sedemikian baik serta semakin maju. Oleh karenanya, sekolah kejuruan dituntut untuk memberikan bekal pendidikan yang cukup dan baik sebelum mereka diterjunkan pada kerja lapangan. Hal ini sesungguhnya dapat membantu anak-anak didik untuk kemudian bisa berpikir entrepreneur. Sehingga komitmen pihak pemegang kebijakan sekolah kejuruan pun sangat dituntut untuk diproyeksikan secara kongkrit dan praksis. Pihak sekolah kejuruan sangat bertanggung jawab terhadap nasib anak-anak didiknya.

Sebab ini berbicara bekal hidup mereka saat selesai dari bangku sekolah. Ada beberapa hal yang perlu diperhatikan pihak pemegang kebijakan sekolah kejuruan supaya pendidikan entrepreneurnya bisa dijalankan secara dinamis dan membuahkan hasil memuaskan. Pertama, sekolah harus mampu memetakan seberapa banyak anak negeri yang tidak melanjutkan pendidikannya ke pendidikan tinggi. Hal demikian perlu ditanggapi, dipertimbangkan dan dijadikan bahan pertimbangan secara serius guna menjadikan sekolah kejuruan yang betul-betul berpihak pada pemberdayaan anak-anak yang jauh dari akses pendidikan tinggi. Kedua, menyusun materi ajar yang applicable guna memberikan bekal pendidikan praksis juga perlu disiapkan secara matang. Sekolah kejuruan mempersiapkan bahan ajar yang dapat diserap sangat mudah oleh anak-anak didik. Materinya lebih diorientasikan pada pembentukan karakter, motivasi, semangat hidup, kreatifitas dan produktifitas.

\section{Menghidupkan Balai Latihan Kerja}

Tanpa menafikan tingkat ekonomi penduduk di negeri ini, sangat banyak anak negeri yang tidak bisa bersekolah sampai Sekolah Menengah Pertama, Sekolah Menengah Atas (SMA) dan sederajat sebab orang tua mereka sangat jauh dari kehidupan ekonomi yang layak. Untuk memenuhi kebutuhan hidup sehari-hari pun, penduduk di negeri ini banting tulang untuk mendapatkan pendapatan yang layak. Ini adalah potret bangsa di negeri tercinta ini. Oleh karena itu, Balai Latihan Kerja (BLK) sangat diminta untuk hadir guna membantu anak-anak yang tidak berpendidikan dan tidak memiliki pengalaman kerja sama sekali supaya mereka kemudian mendapat ilmu baru yang bisa dimanfaatkan sebagai media mencari pekerjaan atau berwirausaha secara mandiri. Yang jelas, peran BLK sangat membantu memberikan ilmu pendidikan terapan alternatif bagi mereka yang tidak mempunyai pengalaman pendidikan kerja sama sekali.

Sebab di BLK itu, mereka kemudian akan dididik, diberi materi sesuai dengan program yang diambilnya saat mendaftar sebagai peserta pendidikan dan pelatihan (diklat) di BLK. BLK sangat berperan besar untuk mengurangi jumlah pengangguran di negeri ini. Sangat jelas pula, mencermati program pendidikan dan pelatihan 
yang selama ini digelar oleh BLK, maka kurikulum pendidikannya pun sangat aplikatif, lebih banyak praktik dari pada teori. Dengan jangka waktu relatif pendek berkisar 3 bulan hingga 6 bulan, maka BLK sudah bisa melahirkan anakanak didik yang siap bekerja, melahirkan lapangan pekerjaan sendiri yang sesuai dengan minatnya serta mampu hidup mandiri secara ekonomi. Oleh karenanya, BLK dalam konteks ini merupakan lembaga pendidikan non-formal yang disiapkan untuk melakukan pendidikan dan pelatihan bagi mereka yang tidak memiliki keahlian tertentu untuk berwirausaha.

\section{Komitmen Politik Pemerintah}

Apapun yang telah dilakukan pendidikan tinggi, sekolah maupun BLK tidak akan berjalan maksimal dan optimal apabila tidak didukung oleh komitmen politik pemerintah baik pusat maupun daerah. Dukungan politik pemerintah sangat menentukan berhasil atau tidaknya sebuah pendidikan. Dalam konteks ini, pemerintah seyogyanya juga mau menyediakan dana yang cukup supaya proses pendidikan bisa berjalan dan dijalankan secara lancar. Keseriusan pemerintah untuk memerhatikan nasib anak-anak negeri yang menganggur sangat ditagih kepeduliannya. Sebab nasib dan masa depan mereka juga menjadi tanggung pemerintah sebagai pelayan dan pemenuh hajat hidup orang banyak di negeri ini. Pemerintah jangan terlalu dan selalu disibukkan dengan kepentingan politik praktis dan pragmatis yang kemudian menelantarkan sekaligus menggadaikan kepentingan bangsa lebih besar di atas kepentingan-kepentingan sempit lainnya.

Oleh karenanya, program pemberdayaan rakyat harus diintensifkan. Mendukung setiap program lembaga pendidikan yang bersentuhan langsung dengan kepentingan rakyat kecil jangan berhenti di tingkat wacana semata, diperlukan kelanjutan dengan memberikan dana bantuan cukup bagi keberlangsungan pendidikan tersebut. Apabila pemeritah sudah tidak sanggup membuka lapangan pekerjaan, maka program-program pendidikan yang sudah disiapkan dan digelar oleh lembaga pendidikan diharapkan diberi perhatian secara optimal. Ini berbicara masa depan bangsa dan rakyat di negeri ini. Oleh karenanya, pemerintah sangat bertanggung jawab terhadap perjalanan hidup bangsa dan rakyat ini.

Program pendidikan yang berjiwa entrepreneur harus diberi ruang sangat luas dan leluasa oleh pemerintah. Pemerintah daerah dalam konteks ini berperan penting untuk menggalakkan pendidikan kewirausahaan. Pemerintah daerah yang menaungi sekolah-sekolah kejuruan di bawah kendali langsung dinas pendidikan kota/ kabupaten diharapkan mampu memberikan dukungan sangat kuat terhadap sekolah-sekolah kejuruan. Dukungan itu mencakup kesediaan sumber dana dan pelengkap-pelengkap lain yang dibutuh-pentingkan oleh sekolah-sekolah kejuruan. Komitmen politik pemerintah sangat ditagih untuk merealisasikan dukungan kongkrit tersebut terhadap sekolah-sekolah kejuruan

Begitu pula dengan Balai Latihan Kerja (BLK) sebagai lembaga pendidikan alternatif yang juga ikut menolong anak-anak yang tidak mampu melanjutkan pendidikannya ke jenjang lebih tinggi seperti sekolah kejuruan atau sekolah menengah atas lainnya harus mendapatkan kepedulian politik sangat tinggi dari pemerintah daerah. Dinas Tenaga Kerja dan Transmigrasi yang menaungi BLK secara garis koordinatif diharapkan memberikan dukungan politik sangat dinamis dan konstruktif demi keberlangsungan BLK tersebut. Eksistensi BLK harus diupayakan pemberdayaannya secara optimal dan maksimal. BLK merupakan tulang punggung lembaga pendidikan yang bisa membekali para anak yang tidak mampu secara finansial. 
Sedangkan pendidikan tinggi dengan program studinya yang lebih kongkrit dan aplikatif sudah sewajarnya pula perlu dikembangkan dengan sedemikian baik dan dinamis. Pendidikan tinggi dengan program studinya yang berorientasi pada entrepreneur harus diperbanyak oleh perguruan tinggi terkait dengan tetap mendapat dukungan kuat dari pemerintah pusat. Sehingga apabila halhal sedemikian mampu dipenuhi dengan baik, sangat mungkin tingkat pengangguran di negeri akan bisa diatasi secara berangsur-angsur. Dalam titik frekuensi tertentu, jumlah pengangguran di negeri akan terkurangi. Sebab mereka, peserta didik di pendidikan tinggi sudah dibekali dengan sekian ilmu terapan yang dapat mengembangkan potensi dan kemampuan dirinya untuk menciptakan lapangan pekerjaan sendiri, tanpa harus bergantung pada pemerintah.

\section{Peran Masyarakat}

Masyarakat harus bisa memantau terhadap segala hal terkait dengan proses pendidikan yang digelar lembaga pendidikan. Mereka harus secara intensif dan ekstensif memonitor apapun yang dilakukan lembaga pendidikan. Tanggung jawab masyarakat secara maha utama adalah memberikan kritik pedas dan tajam tatkala lembaga pendidikan mengalami pergeseran arah pendidikan secara ideal. Awalnya, pendidikan entrepreneur diarahkan membentuk karakter, minat, motivasi, kreatifitas dan produktitas berpikir dan bertindak bagi anak didik, pendidikan entrepreneur ternyata berkutat pada teori semata sebab para penyelenggara pendidikan sudah berpikiran lain, yakni menjadikan lembaga pendidikan sebagai ajang untuk mengeruk uang rakyat demi kepentingan pribadi dan golongan namun tidak memberikan nilai apapun yang berharga bagi masa depan anak didik. Para penyelenggara pendidikan sudah lesu untuk mau berpikir mengenai konsep pendidikan entrepreneur yang lebih baik ke depannya.
Persepsi harus diluruskan bahwa kepentingan entrepreneurship ini adalah penyiapan generasi entrepreneur untuk menyelamatkan Indonesia dari bencana pengangguran, penguasaan sumber daya alam oleh bangsa asing,ketertinggalan dan rendahnya daya saing dalam konteks perdagangan dunia, serta rasa'inferior'yang terus menghinggapi diri orang Indonesia.Sekali lagi ditegaskan mulailah dari lingkungsn terkecil yaitu keluarga dengan satu rujuan mulia mengajarkan entrepreneur agar dapat menyelamatkan bangsa kita tercinta.

\section{PENUTUP}

Kemiskinan menjadi jalan masuknya penjajahan abad baru. Generasi yang akan datang harus dapat memperjuangkan kekayaan bangsa ini, pendidikan entrepreneurship sebagai salah satu jalan untuk mengurangi kemiskinan. Dalam prosesnya seorang entrepreneur terbentuk dari berbagai keadaan atau dorongan yang akan menemukan momentumnya manakala muncul pada saat yang tepat,ada kompetensi dan keahlian, serta benarbenar merupakan terobosan baru. Menjadi kewajiban kita semua untuk meluruskan mindset tentang harapan para orang tua bahwa sukses adalah menjadi dokter, insinyur, dosen, arsitek ataupun astronot dengan mengubah mindset harapan dan cita-cita apapun harus benar-benar didukung tanpa melupakan jiwa pengusaha atau entrepreneur.

Pendidikan entrepreneur harus dimasukkan dalam manajemen anak bagi para orang tua dimana para orang tua harus mampu mempersiapkan mental, ilmu, dan ketrampilan yang memadai pada usia-usia tertentu anaknya. Gerakan pendidikan entrepreneur harus dimulai sejak dari, PAUD, TK, SD, SMP, SMA, PT dengan memasukkan kurikulum kewirausahaan. Pendidikan mempunyai peranan yang sangat penting untuk kemajuan suatu bangsa. Pendidikan entrepreneur adalah satu konsep pendidikan yang 
memberikan semangat pada peserta didik untuk kreatif dalam mengerjakan sesuatu hal. Pola pendidikan sedemikian ini menuntut peserta didik untuk bisa produktif. Pendidikan entrepreneur adalah kerangka pendidikan yang mengarahkan peserta didik untuk bisa cepat dalam memahami dan menelisik kebutuhan sosial sekitar. Peserta didik diharapkan dapat menggali potensi dirinya dengan sedemikian mendalam dan serius. Sebab setiap peserta didik itu memiliki potensi beragam yang tidak bisa disamakan setiap individunya. Sebab mereka beragam dalam segala kebutuhan sosial sekitar.

Kepedulian pemerintah menjadi penentu terwujudnya pendidikan berbasis entrepreneur. Pendidikan tinggi, sekolah maupun BLK tidak akan berjalan maksimal dan optimal apabila tidak didukung oleh komitmen politik pemerintah baik pusat maupun daerah. Dalam konteks ini, pemerintah seyogyanya juga mau menyediakan dana yang cukup supaya proses pendidikan bisa berjalan dan dijalankan secara lancar. Keseriusan pemerintah untuk memerhatikan nasib anakanak negeri yang menganggur sangat dituntut kepeduliannya. Masyarakatpun harus lebih aktif dan intensif dalam memantau perkembangan pendidikan di negeri ini kalau ingin bangsanya maju, tidak hanya menghasilkan bangsa kuli dengan mengirim TKI ke luar negeri yang sebagian besar sebagai pembantu. Negara yang kaya raya akan sumber daya alam ini bila didukung sumber daya yang memiliki spirit entrepreneur yang tinggi akan menjadi Negara yang makmur sehingga dengan sendirinya kemiskinan akan menjadi sejarah dan hanya ada dimusium.

\section{DAFTAR PUSTAKA}

Ciputra. 2009. Ciputra Quantum Leap Entrepreneurship: Mengubah Masa Depan Anda dan Masa Depan Bangsa. Jakarta: Elexmedia.

Eka Dharma Pranoto. 2009. The Next Millionare: Pendidikan Bisnis Praktis Untuk Anak Anda. Jogjakarta: Penerbit Andi.

http//guru preneur. wordpress. Com.

Julian Eka Putra dan Bambang Trim. 2008. Becoming An Entrepreneur is Easy. Surabaya: MIC.

kampus. okezone. com//Kurikulum pendidikan Entrepreneur.

Riant Nugroho. 2009. Memahami Latar Belakang

Pemikiran Entrepreneurship Ciputra:

Membangun Keunggulan Bangsa dengan

Membangun Entrepreneur. Jakarta:

Elexmedia.

Valentino Dinsi dan Laura Khalida. 2007. Mengajari Anak Bisnis: Hanya untuk Orang Tua yang Ingin Anaknya Jadi Pengusaha. Jakarta; Wijawiyata Media Utama. 